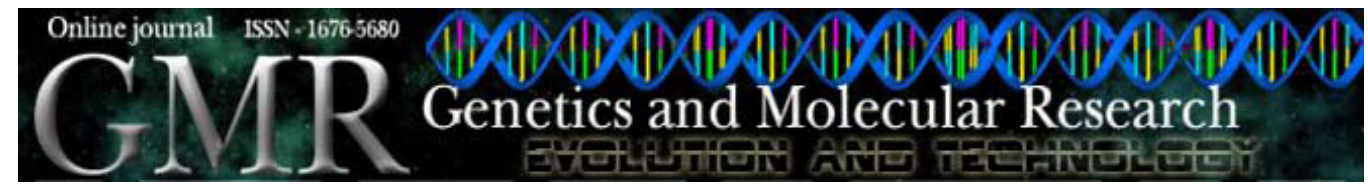

\title{
Compatibility of interspecific Manihot crosses presaged by protein electrophoresis
}

\author{
N.M.A. Nassar, N. Bomfim, A. Chaib, L.F.A. Abreu and P.T.C. Gomes \\ Departamento de Genética e Morfologia, \\ Universidade de Brasília, Brasília, DF, Brasil \\ Corresponding author: N.M.A. Nassar \\ E-mail: nagnassa@rudah.com.br
}

Genet. Mol. Res. 9 (1): 107-112 (2010)

Received September 24, 2009

Accepted October 19, 2009

Published January 19, 2010

\begin{abstract}
Cross incompatibility of wild Manihot species with cassava (M. esculenta) can impede their utilization for improving this cultigen. We tested whether compatibility could be determined based on electrophoresis results. Manihot pilosa, M. glaziovii, $M$. reptans, and $M$. cearulescens were tested. These species were allowed to hybridize with cassava to determine whether hybridization coincides with the similarity index based on electrophoresis analysis. Gene markers of leaf shape, stem surface, disk color, and fruit shape were used to confirm hybridization. Manihot pilosa and M. glaziovii successfully hybridized with cassava, while the others failed to do so under natural conditions. This result coincided with the similarity index from electrophoresis.
\end{abstract}

Key words: Interspecific crosses; Marker genes; Manihot;

Wild cassava species 


\section{INTRODUCTION}

Wild Manihot species are sources of many useful characters for improving cassava (Nassar, 1978a,b,c,d; 2000, 2006a; Nassar and Sousa, 2007). Transfer of these genes, however, faces the problem of interspecific barriers, which impede successful crosses.

To facilitate crosses aimed at transferring useful genes from the wild plants to the cultigen, it is necessary to know how much is the distance between a certain wild species and the cultivated crop, and consequently how strong or weak are the barriers.

Grattapaglia et al. (1986) analyzed biosystematically the relationship between cassava and its wild relatives on the basis of protein electrophoresis. They constructed a species similarity matrix based on band density and number. Some enquiries were raised as to how much this relationship is reflected in trial crosses and in fertility. In this paper, a trial was designed to hybridize 4 species representative of wild Manihot groups with the cultigen. They were selected because they represent botanically the extreme ends of distance to cassava (Rogers and Appan, 1973; Nassar, 2003a,b). Our idea is that the more hybrid seed obtained the greater the relationship and compatibility are.

\section{MATERIAL AND METHODS}

Four wild species in addition to cassava were used in this experiment. These species are: Manihot pilosa, M. glaziovii, M. reptans, and M. cearulescens. Seeds and or cuttings of these species were planted in September 2000.

The seeds were treated thermally by alternating temperatures of $16^{\circ}$ and $28^{\circ} \mathrm{C}$ for periods of 8/16 h (Nassar, 1983; Nassar, 2006b; Nassar and Hashimoto, 2006) for one week to break dormancy. Mode of planting was in circles where one plant of the wild species was in the center of a circle of 8 cassava plants. They were allowed to pollinate by insects. Fruits were collected from the wild species (maternal parent) in the third year, June 2002. Seeds were extracted from fruits, treated thermally to break dormancy and planted in rows. Raised plants were observed using gene markers to identify interspecific hybrids. These marker genes are dominant genes of prominent nodes on stem (which came from cassava, the paternal parent) versus smooth stem, red color of flower disk, which is dominant to yellow, setaceous bracteole, which is dominant to foliaceous, and winged fruit, which is dominant to globose one. The plants raised were also examined for growth habit, height, stem texture, and tuber formation.

\section{RESULTS AND DISCUSSION}

Of 200 seeds of M. pilosa, only 39 seedlings emerged of which 4 hybrids were identified by dominant markers from cassava: noded stem, setaceous bracteoles, ribbed fruit, and tuberous roots (Table 1). Other characters proved to be indirect evidence of hybridization.

\begin{tabular}{llll}
\multicolumn{2}{l}{ Table 1. Growth habit and marker genes of Manihot species. } & \multicolumn{1}{c}{ Cassava } & Hybrid \\
\hline Character & \multicolumn{1}{c}{ M. pilosa } & Medium shrub 3 m \\
\hline Growth habit & Tall shrub 4 m in height & Small shrub 1.5-2 m & Hairy \\
Young stem texture & Hairy & Glabrous & Setaceous \\
Bracteoles & Setaceous & Setaceous & Ovoid, ribbed \\
Fruits & Globose without ribs & Ovoid, ribbed & Red \\
Flower disk color & Yellow & Red & Forms tubers \\
Tuber formation & None & Forms tubers & \\
\hline
\end{tabular}


The 200 seeds collected from M. glaziovii gave rise to 78 seedlings. Of these, three seedlings showed characteristics of interspecific hybridization. Hybrid plants exhibited dominant phenotypes of cassava, namely ribbed fruit, red color of flower disk, noded stem, and tuberous roots (Figures 1-4; Table 2).

Table 2. Comparison of morphological characters of Manihot glaziovii, cassava and their hybrid.

\begin{tabular}{llll}
\hline Character & \multicolumn{1}{c}{ M. glaziovii } & Cassava & Hybrid \\
\hline Growth habit & Tree $10 \mathrm{~m}$ in height & Erect shrub 1.5-2 $\mathrm{m}$ & Erect shrub 2.5-3 m \\
Young stem texture & Glabrous & Glabrous & Glabrous \\
Bracteoles & Setaceous & Setaceous & Setaceous \\
Fruits & Globose without ribs & Ovoid, ribbed & Ovoid, ribbed \\
Flower disk color & Yellow & Red & Red \\
Steam nodes & Smooth & Prominent & Prominent \\
Tuber formation & None & Forms tubers & Forms tubers \\
\hline
\end{tabular}

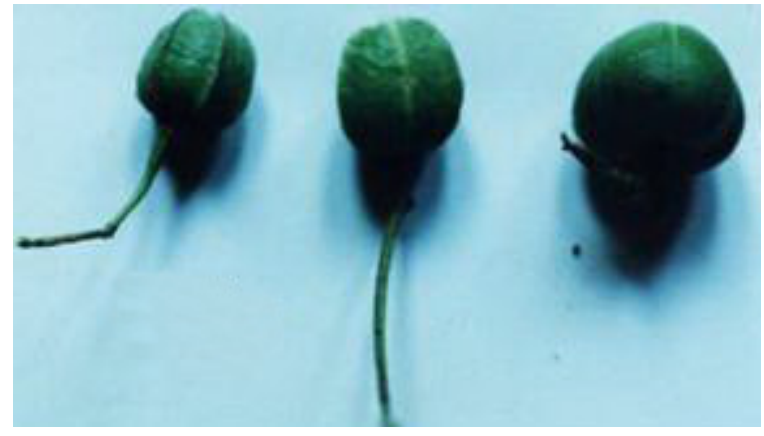

Figure 1. Marker gene of fruit shape; winged fruit.

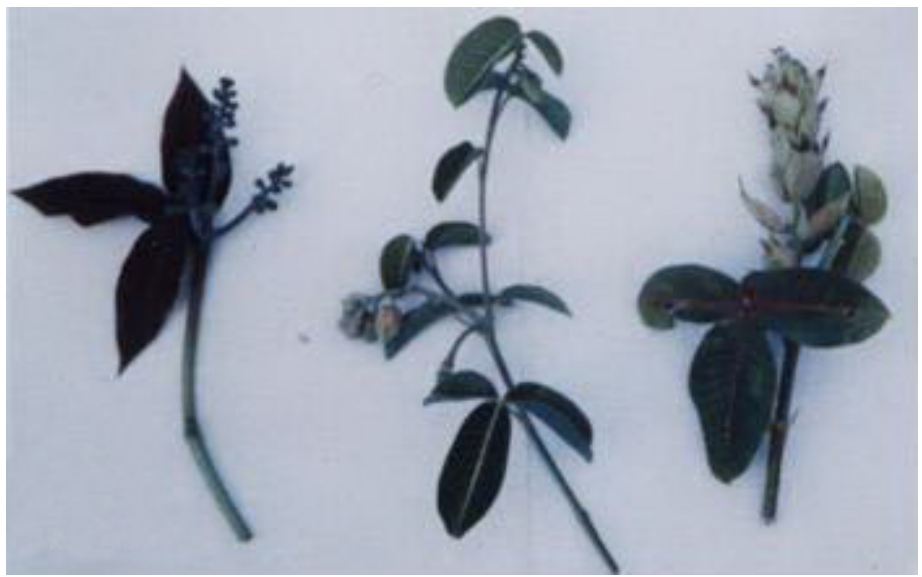

Figure 2. Red flower disk (left), globose fruit (right) and hybrid fruit (middle), and yellow disk. 


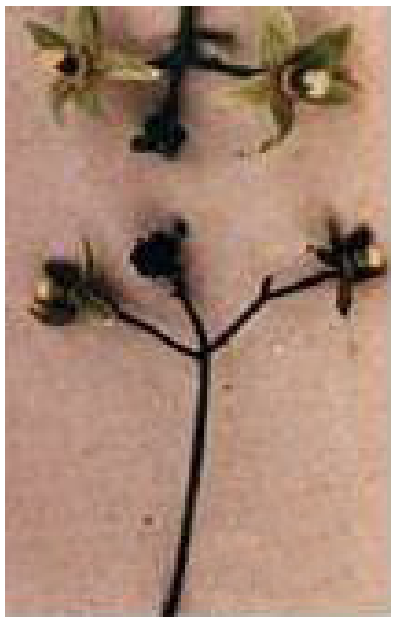

Figure 3. Foliaceous (above) and setaceous bracteole (below).

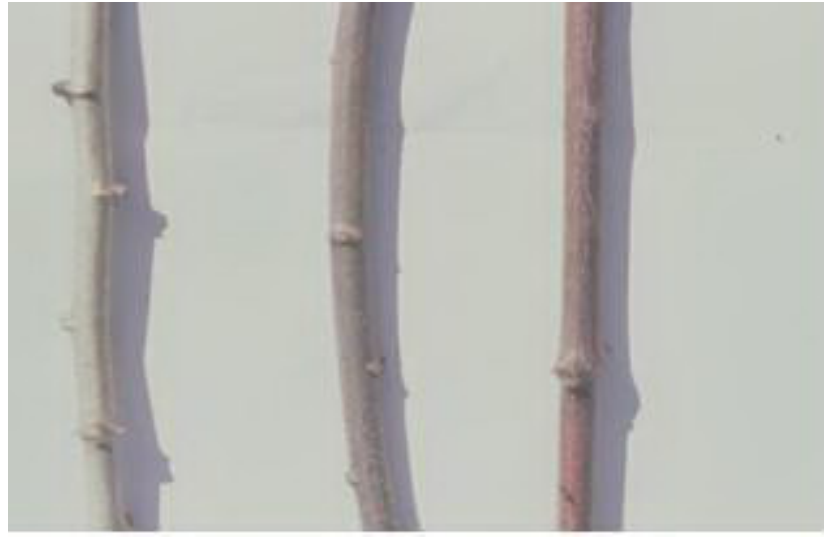

Figure 4. Smooth stem (right), noded stem (left) and hybrid form (middle).

These results show that glabrous stem, setaceous-folicaceous bracteoles, redcreamy color of flower disks, variegated-green color of fruit, and ribbed-nonribbed fruit are simple marker genes that can be used to recognize interspecific hybridization. This is in accordance with what was found by Nassar in 1989 while working with broadening the genetic base of Cassava by controlled hybridization.

Species of $M$. reptans and M. cearulescens did not produce any hybrid within 200 seeds collected from each of them. In their biosystematic analysis of Manihot species using electrophoresis of soluble protein, Grattapaglia et al. (1986) elaborated a matrix of similarity index for cassava and other wild Manihot species examined as shown in Table 3. 


\begin{tabular}{|c|c|c|c|c|c|c|c|c|c|c|c|c|c|c|c|c|c|c|c|c|c|c|}
\hline \multirow{3}{*}{$\begin{array}{l}\text { Section } \\
\text { species }\end{array}$} & \multicolumn{22}{|c|}{ Section } \\
\hline & \multicolumn{2}{|c|}{ I } & \multicolumn{5}{|c|}{ II } & \multicolumn{4}{|c|}{ III } & \multirow{2}{*}{$\frac{\mathrm{IV}}{\mathrm{L}}$} & \multirow{2}{*}{$\frac{\mathrm{V}}{\mathrm{M}}$} & \multicolumn{2}{|c|}{ VI } & \multirow{2}{*}{$\frac{\text { VII }}{P}$} & \multirow{2}{*}{$\frac{\text { VIII }}{Q}$} & \multicolumn{3}{|c|}{ IX } & \multirow{2}{*}{$\frac{\mathrm{X}}{\mathrm{U}}$} & \multirow{2}{*}{$\frac{-}{\mathrm{V}}$} \\
\hline & A & B & C & D & E & F & G & $\mathrm{H}$ & I & $\mathrm{J}$ & K & & & $\mathrm{N}$ & $\mathrm{O}$ & & & $\mathrm{R}$ & $\mathrm{S}$ & $\mathrm{T}$ & & \\
\hline A & - & 78 & 54 & 45 & 67 & 64 & 58 & 66 & 64 & 58 & 58 & 58 & 50 & 45 & 43 & 43 & 54 & 30 & 32 & 54 & 47 & 50 \\
\hline B & & - & 49 & 38 & 68 & 68 & 68 & 61 & 60 & 56 & 54 & 50 & 52 & 42 & 41 & 44 & 52 & 28 & 31 & 53 & 43 & 50 \\
\hline C & & & - & 62 & 51 & 65 & 48 & 51 & 49 & 51 & 54 & 54 & 59 & 31 & 30 & 32 & 45 & 33 & 33 & 50 & 44 & 40 \\
\hline D & & & & - & 47 & 53 & 65 & 40 & 45 & 40 & 50 & 54 & 47 & 30 & 29 & 30 & 39 & 32 & 33 & 50 & 39 & 59 \\
\hline E & & & & & - & 75 & 61 & 70 & 75 & 63 & 74 & 66 & 62 & 46 & 44 & 45 & 60 & 36 & 39 & 66 & 53 & 62 \\
\hline $\mathrm{F}$ & & & & & & - & 58 & 67 & 71 & 67 & 70 & 70 & 71 & 42 & 40 & 41 & 58 & 36 & 38 & 58 & 56 & 56 \\
\hline G & & & & & & & - & 51 & 54 & 51 & 65 & 65 & 52 & 38 & 39 & 38 & 50 & 34 & 36 & 50 & 41 & 78 \\
\hline $\mathrm{H}$ & & & & & & & & - & 74 & 71 & 60 & 55 & 61 & 49 & 50 & 48 & 56 & 35 & 37 & 64 & 54 & 52 \\
\hline I & & & & & & & & & - & 59 & 64 & 70 & 45 & 45 & 43 & 43 & 62 & 41 & 45 & 70 & 69 & 60 \\
\hline J & & & & & & & & & & - & 74 & 55 & 52 & 43 & 41 & 42 & 52 & 45 & 44 & 36 & 49 & 48 \\
\hline K & & & & & & & & & & & - & 71 & 59 & 41 & 39 & 38 & 52 & 32 & 34 & 37 & 47 & 54 \\
\hline L & & & & & & & & & & & & - & 59 & 38 & 39 & 46 & 56 & 33 & 36 & 38 & 51 & 59 \\
\hline M & & & & & & & & & & & & & - & 40 & 35 & 50 & 50 & 32 & 35 & 37 & 47 & 50 \\
\hline $\mathrm{N}$ & & & & & & & & & & & & & & - & 78 & 55 & 50 & - & 88 & 38 & 43 & 42 \\
\hline $\mathrm{O}$ & & & & & & & & & & & & & & & - & - & 51 & & - & 39 & 37 & 43 \\
\hline$P$ & & & & & & & & & & & & & & & & & 36 & & & - & 48 & 41 \\
\hline Q & & & & & & & & & & & & & & & & & & & & & 49 & 56 \\
\hline $\mathrm{R}$ & & & & & & & & & & & & & & & & & & & & & 49 & 36 \\
\hline S & & & & & & & & & & & & & & & & & & & & & 50 & 38 \\
\hline $\mathrm{T}$ & & & & & & & & & & & & & & & & & & & & & & \\
\hline U & & & & & & & & & & & & & & & & & & & & & 43 & 58 \\
\hline
\end{tabular}

This index was based on quantifying density and distance of bands. From this matrix, it is seen that M. pilosa and M. glaziovii (referred to by the letters H and I, and cassava referred to by the letter A) have the highest similarity indices, i.e., $68 \%$ for $M$. pilosa and $64 \%$ for M. glazio$v i i$. The similarity indices for species $M$. reptans and M. cearulescens are far lower. These species are referred to by the letters $\mathrm{S}$ and $\mathrm{U}$, having a similarity index of 32 and $47 \%$, respectively.

Apparently the weak barriers between cassava and M. glaziovii and M. pilosa could be broken, while the stronger ones with the other two species could not be easily overcome (Nassar 2006c,d).

From our observations in this experiment, insect pollination played an important role in obtaining successful crosses. This is probably due to the fact that insects as vectors carry abundant amounts of cassava pollen grains from one flower to another (Nassar, 2004, 2007a). This means a great diversification of gametes, which is available when manual crosses are applied.

We can conclude that barriers between cassava and other Manihot species are weak and recently evolved. A similar deduction has been previously made by Nassar et al. (1995, 1997). It seems that they arose not as a primary isolating event, but secondarily after geographic isolation. Nassar $(1978 c, 1984,1985,2007 b)$ postulated that cassava itself is an interspecific hybrid, which appeared by domestication some 3000 years ago or less.

\section{ACKNOWLEDGMENTS}

Research supported by Conselho Nacional de Desenvolvimento Cientifico - CNPq. The above mentioned living collection was established with the support of the Canadian International Development Research Center, Ottawa, to which we are grateful. 


\section{REFERENCES}

Nassar NMA (1978a). Conservation of the genetic resources of cassava (Manihot esculenta). Determination of wild species localities with emphasis on probable origin. Econ. Bot. 32: 311-320.

Nassar NMA (1978b). Genetic resources of cassava - Chromosome behavior in some wild Manihot species. Indian J. Genet. Plant Breed. 38: 135-137.

Nassar NMA (1978c). Hydrocyanic acid content in some wild Manihot (cassava) species. Can. J. Plant Sci. 58: 577-578.

Nassar NMA (1978d). Microcenters of wild cassava, Manihot ssp diversity in central Brazil. Turrialba 28: 345-347.

Nassar NMA (1983). A quebra da dormência da semente das espécies selvagens da mandioca, Manihot spp. Cienc. Cult. 35: 630-632.

Nassar NMA (1984). Natural hybrids between Manihot reptans Pax and Manihot alutacea Rogers and Appan. Can. J. Plant Sci. 64: 423-425.

Nassar NMA (1985). Manihot neusana Nassar: A new species native to Paraná, Brazil. Can. J. Plant Sci. 65: 1097-1100.

Nassar NMA (1989). Broadening the genetic base of cassava, Manihot esculenta Crantz, by interspecific hybridization. Can. J. Plant Sci. 69: 1071-1073.

Nassar NMA (1997). Development of cassava interspecific hybrids for savanna conditions. J. Root Crops 22: 9-17.

Gratapaglia DE, Nassar NMA and Dianese JC (1986). Biossistemática de espécies brasileiras do gênero Manihot baseada em padrões de proteína da semente. Cienc. Cult. 19: 294-300.

Nassar NMA (2000). Cassava, Manihot esculenta Crantz, genetic resources: their collection, evaluation, and manipulation. Adv. Agron. 69: 179-230.

Nassar NMA (2003a). Cassava, Manihot esculenta Crantz genetic resources VI. Anatomy of a diversity center. Genet. Mol. Res. 2: 214-222.

Nassar NMA (2003b). Gene flow between cassava, Manihot esculenta Crantz, and wild relatives. Genet. Mol. Res. 2: 334-347.

Nassar NMA (2004). Cassava: some ecological and physiological aspects related to plant breeding. Gene Conserv. 3: 229-245.

Nassar NMA (2006a). Letter to the Editor. Genet. Mol. Res. 5: 419-420.

Nassar NMA (2006b). Cassava genetic resources: extinct everywhere in Brazil. Genet. Res. Crop. Evol. 53: 975-983.

Nassar NMA (2006c). The synthesis of a new cassava-derived species, Manihot vieiri Nassar. Genet. Mol. Res. 5: 536-541.

Nassar NMA (2006d). Cassava in South America, Brazil's contribution and the lesson to be learned from India. Genet. Mol. Res. 5: 688-695.

Nassar NMA (2007a). Wild cassava, Manihot spp. to improve the crop. Gene Conserv. 26: 387-414.

Nassar NMA (2007b). Cassava genetic resources and their utilization for breeding of the crop. Genet. Mol. Res. 6: 1151-1168.

Nassar NMA and Hashimoto DYC (2006). Wild cassava, Manihot spp.: a survey of useful species with reference to economic value. Gene Conserv. 5: 284-295.

Nassar NMA and Sousa MV (2007). Amino acid profile in cassava and its interspecific hybrid. Genet. Mol. Res. 6: 292-297.

Rogers DJ and Appan SG (1973). Manihot and Manihotoids (Euphorbiaceae) (Flora Neotropica Monograph, 13). Hafner Press, New York.

Nassar HN, Nassar NMA, Vieira C and Saraiva LS (1995). Cytogenetic behavior of the interspecific hybrid of Manihot neusana Nassar and Cassava, M. esculenta Crantz, and its backcross progeny. Can. J. Plant Sci. 75: 675-678. 